\title{
MENINGKATKAN HASIL BELAJAR MATEMATIKA PADA MATERI KPK DAN FPB DENGAN MENERAPKAN MODEL PEMBELAJARAN KONTEKSTUAL DI KELAS VI SD NEGERI 174/X TRI MULYA
}

\author{
Yantomaisuardi ${ }^{1}$ \\ Guru Sekolah Dasar Negeri 174/X Tri Mulya ${ }^{1}$ \\ E-mail: yantomaisuardi@gmail.com
}

\begin{abstract}
ABSTRAK
Penelitian ini adalah penelitian tindakan kelas yang bertujuan untuk meningkatkan hasil belajar matematika siswa pada materi KPK dan FPB dengan menerapkan model pembelajaran kontekstual di Sekolah Dasar Negeri 174/X Tri Mulya, Tahun Ajaran 2019/2020. Subjek Penelitian Ini Adalah siswa Di Sekolah Dasar Negeri 174/X Tri Mulya, Kecamatan Rantau Rasau, Kabupaten Tanjung Jabung Timur, Propinsi Jambi. Penelitian tindakan kelas ini dilaksanakan dalam dua siklus, setiap siklus terdiri dari dua pertemuan. Hasil evaluasi dikonversikan dengan tabel hasil penyampaian tes belajar siklus I. Hasil konversi menyatakan bahwa penelitian belum mencapai target, perlu dilanjutkan dengan siklus II. Hasil observer pada tahap pelaksanaan siklus II menunjukkan bahwa semua bagian dalam kegiatan pembelajaran sudah berlangsung dengan baik, sehingga tidak ada lagi bagian kegiatan pembelajaran yang perlu diperbaiki. Sedangkan hasil siklus II yang dikonversikan dengan hasil tabel tes belajar menyatakan bahwa penelitian sudah mencapai batas target kriteria ketuntasan belajar yakni sebesar 93,3 dan terjadi peningkatan rata-rata yaitu 50,4 pada kondisi awal perbaikan menjadi 54,2 pada siklus I, dari 54,2 menjadi 75,9 pada siklus II. Dari perbandingan rata-rata menyatakan bahwa kontekstual dapat meningkatkan hasil belajar siswa dalam pembelajaran di Sekolah Dasar Negeri 174/X Tri Mulya, Tahun Ajaran 2019/2020.
\end{abstract}

Kata Kunci: Hasil Belajar; Pembelajaran Kontekstual.

\begin{abstract}
This research is a classroom action research that aims to improve student mathematics learning outcomes in the KPK and FPB material by applying contextual learning models in the 174 / X Tri Mulya State Primary School, Academic Year 2019/2020. The Subjects of this Research are students in 174 / X Tri Mulya Public Elementary School, Rantau Rasau District, Tanjung Jabung Timur Regency, Jambi Province. This class action research was carried out in two cycles, each cycle consisting of two meetings. Evaluation results are converted with a table of the results of the delivery of learning cycle I. The conversion results state that the research has not reached the target, it needs to be continued with cycle II. The results of observers in the implementation phase of the second cycle showed that all parts of the learning activities were going well, so that there were no more parts of the learning activities that needed to be improved. While the results of the second cycle are converted with the results of the learning test table states that the study has reached the target limit of learning completeness criteria that is equal to 93.3 and an average increase of 50.4 in the initial conditions of improvement to 54.2 in the first cycle, from 54,2 to 75.9 in the second cycle. From the comparison of the average stated that contextual can improve student learning outcomes in learning in 174 / X Tri Mulya Public Elementary School, School Year 2019/2020.
\end{abstract}

Keywords: Learning Outcomes; Contextual Learning Models. 


\section{$\pi$ (Phi)}

\section{PENDAHULUAN}

Bangsa yang ingin maju adalah bangsa yang baik pendidikannya, sedangkan bangsa yang buruk pendidikannya tidak akan menjadi bangsa yang maju. Dalam proses belajar mengajar ada tiga komponen yang penting dalam sistem pendidikan nasional yaitu peserta didik, guru dan kurikulum. Ketiga komponen tersebut mempunyai hubungan yang tidak dapat dipisahkan antara yang satu dengan yang lainnya, karena tanpa kehadiran salah satu komponen tersebut proses interaksi edukatif tidak akan terjadi.

Kemampuan teknologi pada abad ke21 membawa pengaruh yang signifikan terhadap bagaimana menyiapkan pendidikan untuk generasi yang akan datang. Oleh karena itu semua komponen dalam pendidikan dituntut untuk menguatkan perannya dalam mewujudkan tujuan pendidikan nasional. UU No 20 tahun 2003 tentang Sistem Pendidikan Nasional Bab II Pasal 3 menyatakan bahwa Pendidikan Nasional bertujuan untuk mengembangkan potensi peserta didik agar menjadi manusia yang beriman dan bertakwa kepada Tuhan Yang Maha Esa, berakhlak mulia, sehat, cakap, kreatif, mandiri dan menjadi warga negara yang demokratis serta bertanggung jawab.

Pendidikan merupakan investasi dalam pengembangan sumber daya manusia dan dipandang sebagai kebutuhan dasar bagi masyarakat yang ingin maju. Pembelajaran terdiri dari sejumlah komponen yang saling berhubungan dan saling mempengaruhi satu sama lain dalam rangka pencapaian tujuan Pembelajaran yang telah dirumuskan. Komponen-komponen tersebut antara lain adalah tujuan Pembelajaran yang ingin dicapai, materi, metode, media, evaluasi, guru, peserta didik, administrasi, sarana dan prasarana

Menurut (Sudaryo,1990:5) Pendidikan adalah usaha sadar dan terencana untuk mewujudkan suasana belajar dan proses pembelajaran agar siswa secara aktif mengembangkan potensi dirinya untuk memiliki kekuatan spiritual keagamaan, pengendalian diri, kepribadian, kecerdasan, akhlak mulia, serta keterampilan yang diperlukan dirinya, masyarakat, bangsa dan negara. Adapun yang dimaksud dengan Pendidikan nasional adalah Pendidikan yang berdasarkan Pancasila dan Undang Undang Dasar Negara Republik Indonesia Tahun 1945 yang berakar pada nilai-nilai agama, kebudayaan nasional Indonesia dan tanggap terhadap tuntutan perubahan zaman. Sedangkan sistem Pendidikan nasional adalah keseluruhan komponen Pendidikan yang saling terkait secara terpadu dalam mencapai tujuan Pendidikan nasional.

Matematika perlu diberikan pada siswa mulai dari sekolah dasar karena dapat membekali siswa untuk memiliki kemampuan berpikir logis, analisis, siswa tematis, kritis, dan kreatif (Susanto,2013: 189).

Terdapat dilapangan yang menunjukkan masih terdapat 7 siswa dari 15 siswa kelas VI SD Negeri 174/X Tri Mulya,yang belum mencapai KKM (Kriteria Ketuntasan Minimal) yaitu 70, sehingga ratarata kelas yang diperoleh adalah 70. Data tersebut diperoleh dari hasil belajar ulangan harian siswa kelas VI SD Negeri 174/X Try Mulya tahun pembelajaran 2019/2020 mata pelajaran matematika pada materi kelipata persekutuan terkecil (KPK) dan factor persekutuan terbesar (FPB).

Proses pembelajaran yang kontekstual atau berdasarkan kondisi nyata yang dialami peserta didik dalam kehidupan sehari-hari akan lebih mudah dipahami dan diserap dengan dengan baik oleh peserta didik Menurut (Sani,2013:41). Ketercapaiannya proses pembelajaran tersebut, juga dapat mempengaruhi hasil belajar siswa selama pembelajaran berlangsung.

Menurut Nurhadi (dalam Sugiyanto, 2009:14) pembelajaran kontekstual (Contextual Teaching and Learning/CTL) merupakan sebuah konsep belajar yang mendorong guru untuk menghubungkan materi pembelajaran dengan dunia nyata 


\section{$\pi$ (Phi)}

siswa. Sehingga dengan menggunakan model pembelajaran ini siswa akan lebih mudah menerima materi yang disampaikan guru karena berdasarkan situasi nyata yang sering dijumpai siswa dalam kehidupan sehari-hari.

Hasil pembelajaran diharapkan lebih bermakna pada siswa, karena proses pembelajaran berlangsung secara alamiah sehingga pada akhir pembelajaran siswa dapat memperoleh hasil belajar yang baik (Daryanto dan Rahardjo2012:153).

Maka penulis ingin melakukan penelitian mengenai peningkatan hasil belajar matematika kelas VI pada materi KPK dan FPB melalui pembelajaran kontekstual. Variabel yang akan diteliti yaitu hasil belajar siswa dan berpikir kritis matematika.

Belajar adalah suatu perubahan dalam diri individu sebagai hasil interaksi lingkungannya untuk memenuhi kebutuhan dan menjadikannya lebih mampu melestarikan lingkungan secara memadai (Durton,2000:19).

James O (2012:122) Wittaker mengemukakan bahwa belajar adalah proses dimana tingkah laku ditimbulkan atau diubah melalui latihan atau pengalaman.

Belajar adalah suatu proses yang ditandai dengan adanya perubahan pada diri seseorang. Perubahan sebagai hasil dari berbagai bentuk seperti perubahan pengetahuan, pemahaman sikap, tingkah laku, ketrampilan, kecakapan, kebiasaan serta perubahan aspek-aspek lain yang ada pada individu yang belajar.

Proses belajar mengajar dapat berjalan dengan baik, peserta didik sebaiknya diajak untuk memanfaatkan semua alat inderanya. Guru berupaya menampilkan rangsangan (stimulus) yang dapat di proses dengan berbagai indera. Semakin banyak alat indera yang digunakan untuk menerima dan mengolah informasi semakin besar kemungkinan informasi tersebut dimengerti dan dapat dipertahankan dalam ingatan. Dengan demikian diharapkan peserta didik akan dapat menerima dan menyerap dengan mudah dan baikpesan-pesan dalam materi yang disajikan.

Nurhadi dalam Rusman, (2010:189) Pembelajaran kontekstual (contextual teaching and learning) merupakan sebuah konsep belajar yang membantu guru untuk mengkaitkan antara materi yang diajarkan dengan situasi dunia nyata siswa. Dengan begitu siswa dapat membuat hubungan antara pengetahuan yang dimilikinya dengan penerapan dalam kehidupan mereka.

Contextual teaching and learning merupakan suatu proses pembelajaran yang holistic dan bertujuan untuk memotivasi siswa dalam memahami makna materi yang diajarkan dengan mengkaitkan materi tersebut dengan konteks kehidupan seharihari (Shoimin,2014:41). Menurut pendapat para ahli maka dapat disimpulkan bahwa (contextual teaching and learning/CTL) merupakan suatu konsep belajar yang mengkaitkan materi pembelajaran dengan kehidupan siswa sehari-hari.

Johnson dalam Depdiknas (2008:9) (contextual teaching and learning/CTL) merupakan suatu proses pengajaran yang bertujuan untuk membantu siswa memahami materi pelajaranyang sedang mereka pelajari dengan menghubungkan pokok materi pelajaran dengan penerapannya dalam kehidupan sehari-hari.

Dari uraian di atas dapat disimpulkan bahwa Pendekatan Kontekstual (contextual teaching and learning/CTL) merupakan konsepsi belajar yang membantu guru dalam mengaitkan bahan ajarannya dengan situasi dunia nyata peserta didik dan mendorong peserta didik membuat hubungan antara pengetahuan yang dimilikinya dengan penerapanya dalam kehidupan sehari-hari.

Langkah-langkah dalam penerapan pembelajaran kontekstual (contextual teaching and learning/CTL) dalam upaya meningkatkan hasil belajar siswa kelas IV SD pada materi KPK dan FPB adalah sebagai berikut:

1. Membangun pengetahuan

2. Siswa menyusun pertanyaan 


\section{$\pi$ (Phi)}

3. Siswa mencari dan menenemukan data

4. Siswa dibagi kedalam kelompok belajar

5. Guru menggunakan media dalam pembelajaran

6. Guru melakukan penilaian

7. Siswa dan guru melakukan refleksi.

Menurut Johnson dan Myklebus dalam (Mulyono Abdurrahman 2003:252) matematika adalah bahasa simbolis yang fungsi praktisnya untuk mengekspresikan hubungan-hubungan kuantitatif dan keruangan sedangkan fungsi teoritisnya adalah untuk memudahkan berpikir.

Lerner dalam Mulyono Abdurrahman (2003, hal. 252) mengemukakan bahwa matematika di samping sebagai bahasa simbolis juga merupakan bahasa universal yang memungkinkan manusia memikirkan, mencatat, mengkomunikasikan ide mengenai elemen dan kuantitas.

Kline dalam Mulyono Abdurrahman (2003:252) juga mengemukakan bahwa matematika merupakan bahas simbolis dan cirri utamanya adalah penggunaan cara bernalar deduktif, tetapi juga tidak melupakan cara bernalar induktif.

Dari beberapa pernyataan diatas, maka dapat disimpulkan bahwa matematika merupakan ilmu yang mempelajari mengenai bilangan-bilangan yang dipelajari dengan menggunakan penalaran untuk melakukan hitungan.

Bahwa faktor persekutuan terbesar (FPB) dari dua bilangan atau lebih merupakan faktor dari bilangan-bilangan tersebut (Yuniarto,2009:36). Dan yang menyatakan bahwa kelipatan persekutuan terkecil (KPK) dari dua bilangan atau lebih adalah sebuah bilangan terkecil yang merupakan kelipatan bilangan tersebut (Yuniarto, 2009: 41).

Berdasarkan dari teori-teori yang mendukung, peneliti mengajukan hipotesis tindakan sebagai berikut Penggunaan pembelajaran kontekstual (Contextual Teaching and Learning/CTL) dapat meningkatkan hasil belajar siswa kelas VI
SD Negeri 174/X Tri Mulya mata pelajaran matematika pada materi KPK dan FPB.

\section{METODOLOGI}

Penelitian ini dilaksanakan pada bulan 6 hingga 12 dengan subjek penelitian siswa kelas VI (eman). Tempat penelitian ini adalah SD Negeri 174/X Tri Mulya. 
Tabel I. Jadwal pelaksanaan penelitian

\begin{tabular}{cll}
\hline No & \multicolumn{1}{c}{ Kegiatan } & Waktu \\
\hline 1. & Membuat proposal & 10 s.d. 15 Juni 2019 \\
2. & Merevisi proposal & 16 s.d 22 Juni 2019 \\
3. & Melaksanakan PTK & 05 Agust s.d 03 okt 2019 \\
4. & Membuat laporan PTK & 04 0kt s.d 12 nov 2019 \\
\hline 5. & Mempresentasikan hasil PTK & Desember \\
\hline
\end{tabular}

Subjek penelitian yaitu siswa kelas VI SDN 174/X Tri Mulya AJaran tahun 2019/2020 jumlah siswa yaitu sebanyak 15 orang yang terdiri dari 7 orang siswa lakilaki dan 8 orang siswa perempuan.

Data teknik pengumpulan data pada penelitian ini adalah teknik non tes dan tes. Teknik non tes digunakan untuk mengetahui kemampuan berpikir kritis siswa, sedangkan teknik tes digunakan untuk mengetahui hasil belajar siswa. Berikut dijabarkan teknik pengumpulan data:

1. Wawancara merupakan teknik pengumpulan data yang dilakukan dengan cara menanyakan secara langsung pada responden mengenai beberapa hal yang dibutuhkan dari suatu penelitian (Ghani, 2014:176). Pada penelitian ini, teknik wawancara yang digunakan adalah wawancara terstruktur. Wawancara dilakukan dengan wali kelas VI dengan tujuan mengetahui kondisi awal siswa dan karakteristik siswa kelas VI.

2. Observasi merupakan aktivitas yang dilakukan denggan menggunakan indra pengelihatan, dan indra pendukung lainnya yang bertujuan untuk mencermati secara langsung fenomena atau obyek yang sedang diteliti (Ghani, 2014:143144).

3. Tes hasil belajar pada penelitian ini, teknik observasi yang digunakan adalah observasi terstruktur. Pada penelitian ini, tes diberikan sebanyak 3 kali, yaitu evaluasi akhir siklus 1, evaluasi akhir siklus 2, dan evaluasi akhir dari siklus 1 dan siklus 2. Bentuk dari tes yang diberikan adalah tes tertulis esai pada masing-masing evaluasi. Setiap soal evaluasi terdapat 5 soal uraian berdasarkan indikator yang akan dicapai dalam pembelajaran.

4. Hasil observasi aktivitas pembelajaran pada setiap siklus dituangkan dalam lembar refleksi, hasil refleksi menjadi dasar perencanaan dan pembuatan RPP siklus berikutnya.

Data hasil observasi yang diperoleh digunakan untuk merefleksi siklus yang telah dilakukan dan diolah secara deskriftif. Analisis data observasi menggunakan skala penelitian(Sudjana, 2006:54). Pengukuran skala penilaian pada proses pembelajaran yaitu antara 1 sampai 3 .

Penentuan nilai untuk tiap kriteria menggunakan persamaan sebagai berikut

1. Rata-rata skor $=\frac{\text { jumlah } \text { skor }}{\text { jumlah } \text { observasi }}$

2. Skor tertinggi $=$ jumlah skor butir $\mathrm{x}$ skor tertinggi setiap kriteria

3. Skor terendah $=$ jumlah kriteria butir $\mathrm{x}$ skor terendah setiap kriteria

4. Selisih skor $=$ skor tertinggi - skor terendah

5. Kisaran nilai tiap kriteria = $\frac{\text { selisih skor }}{\text { jumlah kriteria penilaian }}$ (Sudjana, 2006 : 54).

Pada lembar observasi aktivitas peneliti sebagai guru terdapat 13 butir pertanyaan dengan kriteria penilaian 1 sampai 3. Berdasarkan rumus yang telah disebutkan maka diperoleh data sebagai berikut:

1. Skor tertinggi adalah 45

2. Skor terendah adalah 15

3. Selisih skor 30

4. Kisaran nilai untuk tiap kriteria adalah $\frac{30}{3}=10$. 
Tabel 2. Kriteria penilaian berdasarkan rentang nilai

\begin{tabular}{lcc}
\hline No & Kriteria & Interval \\
\hline 1 & Kurang & $15-25$ \\
2 & Cukup & $25-35$ \\
3 & Baik & $35-45$ \\
\hline
\end{tabular}

Kriteria Keberhasilan, yang menjadi kriteria keberhasilan dalam PTK ini adalah jika hasil belajar mencapai rerata 70 yang berarti bahwa tingkat penguasan kompetensi minimal 70 , dan secara klasikal $75 \%$ tuntas dan jika nilai rerata variable yang diukur oleh lembar observasi keaktifan siswa mencapai kualitas minimal baik atau tinggi.

Jenis penelitian yang akan digunakan oleh peneliti dalam meningkatkan hasil belajar dan berpikir kritis pada mata pelajaran matematika ialah Penelitian Tindakan Kelas (PTK) atau Classroom Action Research (CAR). Menurut Hermawan (2015:13), penelitian tindakan kelas merupakan penelitian yang dilakukan oleh guru di dalam kelas melalui refleksi diri yang bertujuan untuk memperbaiki pembelajaran yang dilakukan sehingga dapat meningkatkan prestasi belajar peserta didik. PTK terdiri dari empat rangkaian kegiatan utama pada setiap siklus, yakni perencanaan. Tindakan, pengamatan dan refleksi

Secara klasikal proses belajar mengajar dikatakan berhasil atau tntas apabila di kelas memperoleh nilai lebih dari $\geq 70$ sebanyak $75 \%$ untuk melihat peningkatan prestasi belajar tersebut dapat digunakan rumus sebagai berikut

1. Nilai rata-rata

$$
\bar{X}=\frac{\sum X}{N}
$$

2. Presentasi ketuntasan belajar klasikal

$$
\overline{k b}=\frac{N 1}{N} \times 100 \%
$$

\section{HASIL DAN PEMBAHASAN}

Peneilitan dengan judul "Peningkatan

Hasil Belajar dan Kemampuan Berpikir Kritis Matematika Kelas VI Pada Materi KPK dan FPB Melalui Pembelajaran Kontekstual SD Negeri 174/X Tri Mulya" yang telah dilaksanakan pada bulan juni sampai bulan desember. menerapkan pembelajaran melalui penerapan model pembelajaran contekstual ini dilakukan dalam dua kali pertemuan. Dari hasil pembelajaran yang dilakukan dapat dideskrisikan aktivitas guru dan siswa selama proses pembelajaran berlangsung.

$$
\text { Analisis terhadap proses }
$$

pembelajaran yang dilakukan oleh dua orang pengamat terhadap aktivitas guru selama kegiatan pembelajaran matematika melalui penerapan model contektual teaching and learning.

Hasil pengamatan dua orang pengamat untuk aktivitas kegiatan guru selama proses pembelajaran 1 diperoleh ratarata skor sebesar 41,2. Rata-rata skor ini termasuk kedalam kriteria "Baik". Lembar observasi aktivitas guru melalui penerapan model contekstual teaching and learning pada siklus 1 terdiri 15 aspek pengamatan, dengan jumlah kriteria penilaian 3. Hasil analisis observasi guru siklus 1 yang dilakukan oleh dua orang pengamat terhadap aktivitas guru terdapat ada 8 kriteria Baik dan 7 kriteria Cukup.

Untuk aktivitas kegiatan siswa selama proses pembelajaran 1 diperoleh ratarata skor sebesar 39,25. Rata-rata skor ini termasuk kedalam kriteria "Baik". Lembar observasi aktivitas siswa melalui penerapan model contekstual teaching and learning pada siklus 1 terdiri 15 aspek pengamatan, dengan jumlah kriteria penilaian 3. Hasil analisis observasi guru siklus 1 yang dilakukan oleh dua orang pengamat terhadap aktivitas guru terdapat ada 3 kriteria Baik dan 12 kriteria Cukup.

Pada siklus 1 pembelajaran matematika melalui penerapan model contekstual teaching and learning dua kategori penilaian, yaitu nilai proses pembelajaran dan nilai akhir. Penilaian 


\section{$\pi$ (Phi)}

proses melalui penerapan model contekstual teaching and learning menggunakan keriteria penilaian observasi guru dan observasi siswa. Sedangkan nilai hasil belajar dilihat dari penilaian tes prestasi belajar siswa.

Penilaian diakhir pembelajaran dengan jumlah soal 5 butir berbentuk essay pada pertemuan 1 dan butir 5 soal essay ada pertemuan II. Yang diperoleh data 15 siswa nilai rata-rata kelas 54,2 dengan ketuntasan belajar 53,3\%. Dari hasil belajar diatass menunjukkan bahwa proses pembelajaran pada siklus 1 belum tuntas, karena sesuai dengan yang dikemukakan oleh Depdiknas (2007:62) bahwa proses pembelajaran dikelas dikatakan tuntas secara klasikal apabila $75 \%$ siswa dikelas mendapatkan nilai $\geq 70$. Setelah melakukan siklus I peneliti melakukan refleksi.

Pelaksanaan tindakan pada siklus II dimulai pada hari Senin 09 Agustus 2019 dan pada hari senin 03 oktober 2019 Penelitian siklus II dilakukan sebanyak dua kali pertemuan, dengan alokasi waktu 2 JP (2 $\times 40$ menit) pada tiap pertemuannya. Pada siklus II kompetensi dasar yang akan dipelajari. Menyelesaikan masalah yang berkaitan dengan KPK dan FPB.

Analisis terhadap proses pembelajaran yang dilakukan oleh dua orang pengamat terhadap aktivitas guru selama kegiatan pembelajaran matematika melalui penerapn model contekstual teaching and learning.

Hasil pengamatan dua orang pengamat untuk aktivitas kegiatan guru selama proses pembelajaran 2 diperoleh ratarata skor sebesar 41,75. Rata-rata skor ini termasuk kedalam kriteria "Baik". Lembar observasi aktivitas guru melalui penerapan model contekstual teaching and learning ada siklus 1 terdiri 15 aspek pengamatan, dengan jumlah kriteria penilaian 3. Hasil analisis

Tabel 3. Hasil observasi aktivitas guru dan siswa pada siklus I Dan siklus II

\begin{tabular}{lclc}
\hline \multicolumn{2}{c}{ Lembar Observasi Guru } & \multicolumn{2}{c}{ Lembar Observasi Siswa } \\
\hline Siklus I & Siklus II & Siklus I & Siklus II \\
41,2 & 41,75 & 39,25 & 42 \\
\hline
\end{tabular}

observasi guru siklus II yang dilakukan oleh dua orang pengamat terhadap aktivitas guru terdapat ada 8 kriteria Baik dan 7 kriteria Baik.

Pengamat untuk aktivitas kegiatan siswa selama proses pembelajaran 2 diperoleh rata-rata skor sebesar 42. Rata-rata skor ini termasuk kedalam kriteria "Baik". Lembar observasi aktivitas siswa melalui penerapan model contekstual teaching and learning pada siklus II terdiri 15 aspek pengamatan, dengan jumlah kriteria penilaian 3. Hasil analisis observasi guru siklus II yang dilakukan oleh dua orang pengamat terhadap aktivitas guru terdapat ada 11 kriteria Baik dan 4 kriteria Cukup.

Pada siklus II pembelajaran Matematika melalui penerapan model contekstual teaching and learning dua kategori penilaian, yaitu nilai proses pembelajaran dan nilai akhir. Penilaian proses melalui penerapan model contekstual teaching and learning menggunakan keriteria penilaian observasi guru dan observasi siswa. Sedangkan nilai hasil belajar dilihat dari penilaian tes prestasi belajar siswa.

Penilaian diakhir pembelajaran dengan jumlah soal 5 butir berbentuk essay pada pertemuan 1 dan butir 5 soal essay ada pertemuan II. Yang diperoleh data 15 siswa nilai rata-rata kelas 75,9 dengan ketuntasan belajar 93,3\%. Dari hasil belajar diatas menunjukkan bahwa proses pembelajaran pada siklus II belum tuntas, karena sesuai dengan yang dikemukakan oleh Depdiknas (2007:62) bahwa proses pembelajaran dikelas dikatakan tuntas secara klasikal apabila $75 \%$ siswa dikelas mendapatkan nilai $\geq 70$.

Hasil observasi terhadap proses pembelajaran yang dilakukan oleh dua orang pengamat terhadap aktivitas guru dan siswa. 


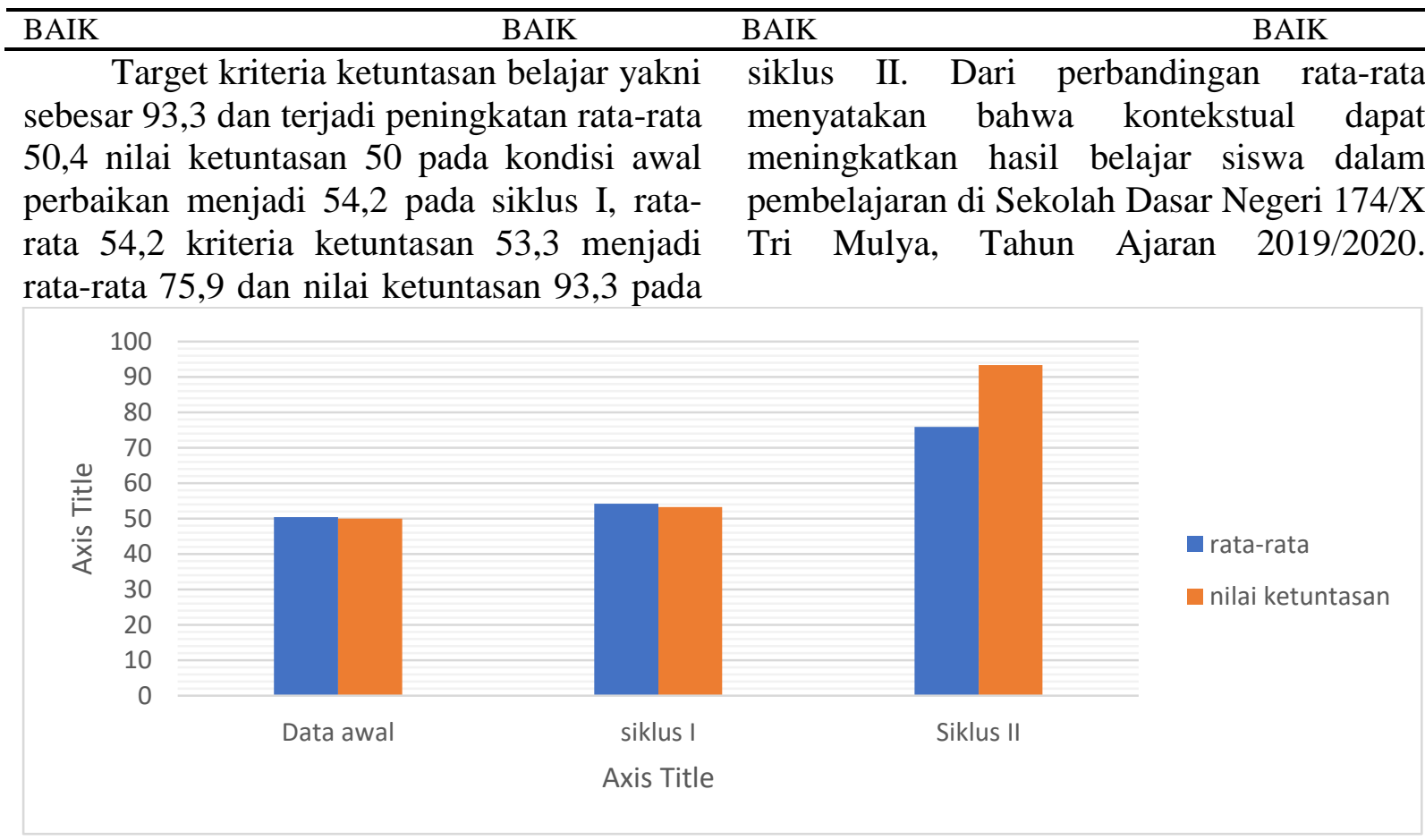

Gambar 1. Deskripsi Siswa

\section{KESIMPULAN DAN SARAN}

Berdasarkan hasil yang telah dicapai dalam pnelitian ini maka dapat ditarik kesimpulan bahwa Upaya peningkatan hasil belajar matematika kelas VI pada materi KPK dan FPB melalui pembelajaran kontekstual telah dilakukan dengan langkahlangkah sebagai berikut: Contructivism, Questioning, Inquiry, Learning Community, Modeling, Authentic Assesment, dan Reflection.

Penggunaan model pembelajaran inovatif dengan pendekatan Contextual Teaching and Learning (CTL) dapat meningkatkan hasil belajar kelas VI SD Negeri 174/X Tri Mulya. Hal ini dapat dilihat dari kondisi awal hasil belajar matematika dengan presentase ketercapaian KKM sebesar 53,3\% dengan rata-rata yang diperoleh 70 meningkat menjadi $73,3 \%$ pada evaluasi siklus I dengan rata-rata 71,1 mencapai $80 \%$ pada evaluasi siklus II dengan rata-rata 78 dan mencapai 93,3\% pada evaluasi akhir dengan perolehan ratarata yaitu 87,7 .
Dalam rangka menyumbang pemikiran untuk meningkatkan hasil belajar dan kemampuan berpikir kritis matematika siswa, maka peneliti menyampaikan saransaran yaitu Sebaiknya penelitian tindakan kelas dilakukan oleh guru kelas agar dapat diketahui lebih jelas faktor yang meningkatkan hasil belajar dan berpikir kritis dan ketika melakukan penelitian, sebaiknya peneliti lebih mempertimbangkan waktu dalam pelaksanaan kegiatan pembelajaran, agar hasil yang didapat lebih optimal.

\section{DAFTAR PUSTAKA}

Abdullah, Sani. (2013). Inovasi Pembelajaran. Jakarta: Bumi Aksara.

Abdurrahman, Mulyono. (2003). Pendidikan bagi Anak Berkesulitan Belajar. Jakarta: Rineka Cipta.

Suprijono, A. (2009). Cooperative Learning, Teori \& Aplikasi PAIKEM. Surabaya: Pustaka Pelajar

Susanto, A. (2013). Teori Belajar dan Pembelajaran di Sekolah Dasar. Jakarta: Kencana Prenadamedia Group 


\section{$\pi$ (Phi)}

Susanto, A. (2013). Teori Belajar dan Pembelajaran di Sekolah Dasar. Jakarta: Kencana Prenada Media Group.

Arikunto. (2008). Penelitian Tindakan Kelas. Jakarta: Bumi Aksara

Aris, Shoimin. (2014). Model Pembelajaran Inovatif dalam Kurikulum 2013. Yogyakarta : Ar-Ruzz Media

Astuti. (2008). Pengembangan Matematika. Jakarta: Grasindo.

Daryanto, dan Mulyo Rahardjo. 2012. Model Pembelajaran Inovatif. Yogyakarta: Gava Media

Depdiknas. (2008). Kurikulum Tingkat Satuan Pendidikan. Jakarta: Dikmenum. Depdiknas.

Dimyati dan Mudjiono. 1999. Belajar dan Pembelajaran. Jakarta: Rineka Cipta.

Johnson, B. E. (2006). Contextual Teaching And learning. Bandung: PT.Mizan.

Suyahman. (2004). Belajar dan Pembelajaran. Surakarta: Usaha Mandiri.

Yuniarto. (2009). Peran pembelajaran matematika. Jakarta : Jurnal.

Rusman. (2012). Model-model Pembelajaran: Mengembangkan Profesionalisme Guru, Jakarta . Raja Grafindo Persada.

Rusman. (2010). Model-model Pembelajaran (Mengembangkan Profesionalisme Guru Edisi Kedua). Jakarta: Raja Grafindo Persada.

Soedjadi. (2000). Kiat Pendidikan Matematika di Indonesia. Jakarta: Direktorat Jendral Pendidikan Tinggi Departemen Pendidikan Nasional.

Nurhadi. (2009). Pembelajaran kontektual \& penerapanya dalam $K B K$. Malang: Universitas Negeri Malang.

Ratnawulan, E. dan Rusdiana. (2015). Evaluasi Belajar. Bandung: CV Pustaka Setia.
Kunandar. (2013). Penilaian Autentik (Penilaian Hasil Belajar Peserta Didikberdasarkan Kurikulum 2013). Jakarta. Raja Grafindo Persada.

Sudjana, Nana. (2010). Cara Belajar Siswa Aktif dalam Proses Belajar Mengajar. Bandung: Sinar Baru Algensindo.

Sudjana. (2006). Metode Statistik. Jakarta: Rineka Cipta

Sugianto,(2009). Model-Model Pembelajaran Inovatif. Surakarta : Panitia Sertivikasi Guru (PSG) Raayon 13.

Sugiyanto. (2010). Model-model Pembelajaran Inovatif. Surakarta :Yuma Pustaka.

Suherman Erman (2003). Strategi Pembelajaran Matematika

Sudaryo, dkk. (1990). Strategi Belajar Mengajar I. Wonosobo: Unnes Press. 